Article

\title{
Promoting Owners' BIM Adoption Behaviors to Achieve Sustainable Project Management
}

\author{
Hongping Yuan ${ }^{1} \mathbb{C}$, Yu Yang $^{2, *}$ and Xiaolong Xue ${ }^{1}$ \\ 1 School of Management, Guangzhou University, Guangzhou 510006, China \\ 2 School of Economics and Management, Southwest Jiaotong University, Chengdu 610031, China \\ * Correspondence: yangyu2017@my.swjtu.edu.cn
}

Received: 20 June 2019; Accepted: 12 July 2019; Published: 18 July 2019

\begin{abstract}
Although building information modeling (BIM) has a promising future in the architecture, engineering and construction industry, its wider adoption and implementation is desired. Grounded with a technology-organization-environment (TOE) framework and the theory of technology acceptance model (TAM), this study extracted "social influence", "organizational support", "BIM technical features", and "government BIM policies" as four key external antecedents-in reference to the particular BIM practices in China-and proposed a model to predict project owners' BIM adoption behaviors. To test the proposed model, structural equation modeling (SEM) analysis was applied for configuration analyses on a sample of 188 project owners from the Chinese construction industry. Results show that BIM technical features, and government BIM policies have positive effects on perceived usefulness, but social influence and organizational support have no significant influence on perceived usefulness. Furthermore, both social influence and BIM technical features have positive effects on perceived ease of use, while organizational support and government BIM policies have no significant influence on perceived ease of use. Attitude plays a significant intermediary role among perceived usefulness, perceived ease of use and behavior intention. Additionally, attitude significantly affects behavior intention, and behavior intention can also affect BIM adoption behavior. This study is the first attempt to investigate project owners' behaviors toward BIM adoption and the findings are expected to provide a better understanding of the essential elements of project owners' BIM adoption behaviors and guide industry practitioners in developing proper strategies to achieve more effective BIM implementation.
\end{abstract}

Keywords: building information modeling; project owner; attitude; behavior; technology acceptance model

\section{Introduction}

In the last decade, with the rise of information technologies (ITs), a paradigm shift of industrial informatization has translated into a critical national strategy [1-3]. As a pillar of the domestic economy, the architecture, construction and engineering (AEC) industry in China is on the cusp of transition from an extensive and high-consumption pattern to a new one driven by high efficiency, sustainability and informatization. According to Eastman et al. [4], BIM is "a new approach to design, construction, and facilities management, in which a digital representation of the building process (is used) to facilitate the exchange and interoperability of information in digital format". Therefore, $\mathrm{BIM}$ is an innovative paradigm of building information digitalization resorting on certain specific technologies or software which integrates cash flows, information flows, logistics throughout the project lifecycle and reduces the information asymmetry, unforeseen changes and re-doings effectively, turning the utopia of construction visualization to reality. In the meantime, existing literature suggests the integration of environment and economic assessment for the promotion of sustainable construction 
is considerably important $[5,6]$, and it happens that BIM is an ideal tool which can integrate the assessment of sustainable construction as well as resource management efficiently, such as benefit-cost analysis of economically sustainable design, energy-consumption analysis for a sustainable built environment assessment, architectural information sharing for sustainable facilities management and stakeholder relationship management. Therefore, a wide adoption and application of BIM is bound to strike and even overturn the traditional development patterns of the Chinese AEC industry, embedding these sustainable assessments throughout project lifecycle and thus contributing to sustainable project management.

As such, BIM adoption has become one of the central topics among AEC studies over the past decade. Previous studies have attempted to determine the major factors motivating BIM adoption among project stakeholders, with the aid of various means including questionnaire surveys, interviews, and case studies. For instance, Cao et al. [7] found that the motivation of design units and general contractors in BIM adoption is closely linked to the characteristics of organizational nature and project scale. Meanwhile, evidence from the comparative case study in China and Australia indicated that BIM adoption strategies vary in building construction and infrastructure engineering industries [8]. There are also studies that have compiled and sorted a collection of factors that influence BIM adoption, such as effective leadership and organizational support [9-12], sufficient BIM human resources [13,14], and the availability of information and technology $[11,15]$. Similarly, the large amount of capital required for BIM adoption and application is also a Gordian knot to be unhitched by potential BIM participants $[13,16,17]$. Moreover, the lack of universal standards of BIM implementation [18] and the indistinct legal bounds of a series of work outcomes related to BIM (such as the BIM model) make the environment of BIM implementation immature, and this restricts the adoption and application of BIM [14].

The above studies are significant in promoting a wider adoption and application of BIM through addressing major barriers. However, unfortunately, the majority of current literature has ignored a vital stakeholder in AEC projects-the project owner, (e.g., government, real estate developers), who takes overall responsibility for project investment, initiation, construction or even the operation and management of facilities. Holding preponderant advantages in project planning and controlling the entire project lifecycle, the project owner could enhance project performance by requiring and driving other stakeholders (such as architects, general contractors and so on) to get involved in BIM adoption and implementation. Some implications from prior literature have proven the important role of the project owner in driving BIM adoption. For example, Ling et al. [19] pointed out that the superiority of project owners can effectively promote the application of innovative technologies. In a recent study, Cao et al. [7] also found that project owners' support for BIM application can facilitate better stakeholder cooperation and get more stakeholders engaged in BIM implementation. However, these studies are mainly conducted based on qualitative analysis or mostly focus on identifying factors hindering BIM acceptance and adoption and, thus, fail to reveal the mechanism that drives BIM adoption behavior. In addition, very limited studies have attempted to investigate project owners' BIM adoption behaviors, though some of them have suggested that project owners are critical in promoting BIM acceptance and adoption.

Given the research gap, we believe that understanding why the project owner adopts BIM is an important step in increasing the use of BIM within projects and potentially improving BIM adoption efficiency. The research questions we are attempting to answer are "What factors influence project owners' acceptance of BIM? And how do these factors result in project owners' final BIM adoption behaviors?" To address these research questions, we have developed and tested a model integrating the TOE framework and the theory of the technology acceptance model (TAM) to explain project owners' BIM adoption behaviors.

We also believe that the lack of a theoretical foundation for this stream of research has limited the contributions of previous research and prevented project stakeholders from understanding what makes effective BIM adoption and implementation. It is necessary to understand the effects of these factors hindering BIM adoption and determine the critical path impact on this behavior to develop effective 
BIM adoption measures and design practical strategies that can lead to wider BIM application. The present study helps BIM researchers describe how project owners' adoption behavior can be driven and pilot project owners make informed decisions as to what strategies they can use to promote BIM application in their projects and organizations.

The rest of this paper is organized as follows. The next section briefly reviews research on BIM adoption factors, the theory of the TAM and the technology-organization-environment framework. Then, we present research hypotheses and the research model, followed by an introduction of the research method including the instrument development and validation process. After that, we present data analyses and results, and suggest the implications for research and practice as well as limitations of the current research. Finally, we conclude this paper with a brief summary in the conclusions.

\section{Literature Review}

\subsection{Influencing Factors of BIM Adoption}

BIM has been recognized as a pivotal information technology in the AEC sectors due to its strength of integrating the continuous flows of funds, information and logistics throughout the project lifecycle [4]. Admittedly, the adoption and application of BIM would inevitably make a profound impact on driving the development of informatization in the AEC industry. Thus, BIM has attracted a lot more attention from AEC researchers in recent years. For instance, $\mathrm{Gu}$ et al. [20] posited that although BIM develops with promising prospects, both technical and non-technical factors hamper its diffusion. Based on BIM implementation practices in China, Cao et al. [7] found that the BIM competitiveness of construction firms is closely related to the social network structure in which they are located. An empirical study by Son et al. [21] showed that top management support, subjective norms, and technical compatibility are most important in affecting designers' BIM adoption. In addition, qualified employees, efficient leadership, the availability of information, and the complexity of the project itself are also fundamental factors for successful BIM implementation [11,13]. Based on investigations on potential BIM adopters in the UK, Howard et al. [22] suggested that performance expectations do not directly affect the adoption bias of BIM potential adopters, but improving the strategic policy and the incentive mechanism would be a great help for accelerating BIM diffusion. Liu et al. [23] pay more attention to factors of BIM cooperation from the individual, technological and organizational dimensions among design and construction firms. For BIM users, more emphasis was placed on the information quality needed when implementing BIM and related exoteric services, because these factors will directly affect their satisfaction with BIM [24]. Additionally, based on institutional theory, Cao et al. [25] found that the homomorphism from both mandatory and imitation systems would significantly affect the application of BIM at the project level, and the support from project owners would be conducive to the acceptance of BIM in certain circumstances. By conducting a case study based on the theory of innovation diffusion, Gledson et al. [26] identified the inter-organizational factors driving BIM diffusion at the project level and provided exhaustive schemes to address the individual, managerial, environmental, and technological challenges experienced by construction firms in the process of BIM diffusion.

\subsection{Technology Acceptance Model}

Currently, the technology acceptance model proposed by Davis [27] (see Figure 1) has become a classical and parsimonious model, which has been widely used to explain the behavior of information technology adoption or acceptance. In line with the TAM, perceived usefulness and perceived ease of use are regarded as two essentials to explain the use of a technology [27]. According to the theoretical framework of the TAM, an individual's information technology adoption behavior is determined by his/her behavioral intention. Moreover, attitude and perceived usefulness influence his/her behavioral intention of using a technology, which would necessarily in turn affect the actual system usage. As a key construct, attitude is influenced by both perceived usefulness and perceived ease of use. Davis [28] 
also found that, to some extent, an individual's perceived ease of use of a particular technology will affect his/her perceived usefulness of this technology. In addition, external variables (such as technical features, user intervention, etc.) can indirectly affect user behavior through perceived usefulness and perceived ease of use [28]. Because there is no specific and strict constraint to external variables, the TAM is powerful in explaining user behavior of an information system with high parsimony and conciseness. As such, the TAM has been widely applied to predict various types of technology acceptance behaviors, including Smart Grid [29], virtual reality [30], LNG [31], and transportation [32]. In the context of BIM adoption, the research of Lee et al. [10] was one of the few existing studies that applied the TAM to investigate the BIM adoption of designers, contractors and engineers. However, it still did not approach the crucial role that project owners play in BIM adoption processes.

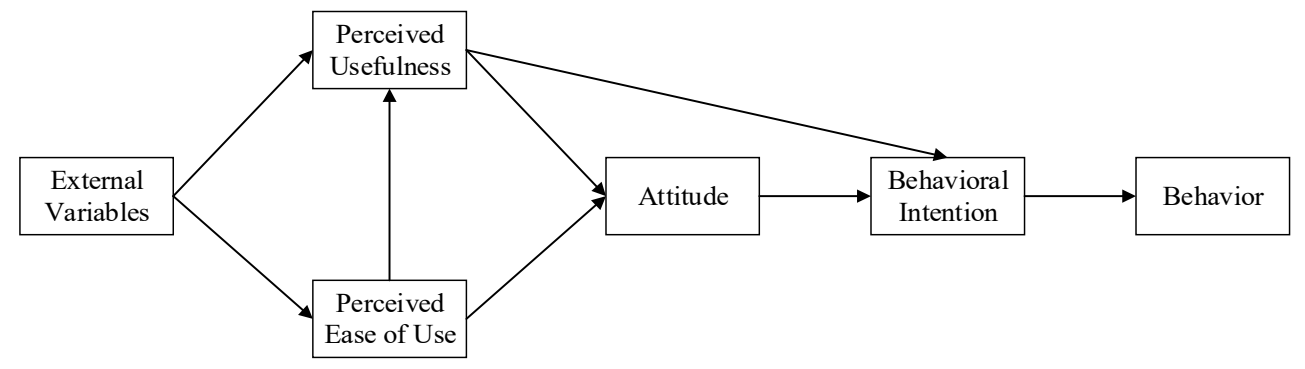

Figure 1. Classical technology acceptance model.

\subsection{Technology-Organization-Environment Framework (TOE)}

The TAM, however, has some limitations when extended beyond the workplace because its fundamental constructs do not fully reflect a variety of the user task environments and constraints. Furthermore, Legris et al. [33] also suggested that the TAM is a useful model but needs to be integrated into a broader model that includes variables related to both human and social factors. To take these limitations of the TAM theory into account, in this present study, we incorporated the technology-organization-environment framework (TOE) (see Figure 2) as the theoretical foundation to clustering various impacts on project owners' BIM adoption. This framework describes factors that influence technology adoption and its likelihood, and the process by which a firm adopts and implements technological innovations is jointly influenced by the technological, organizational, and environmental contexts.

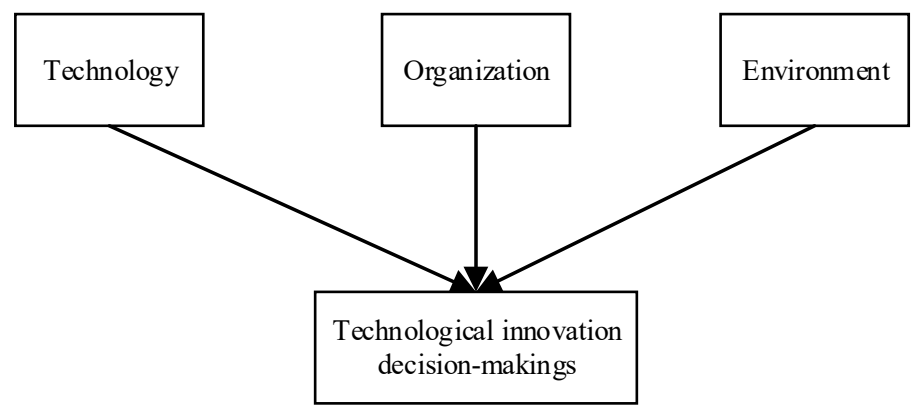

Figure 2. Technology-organization-environment framework.

Since its origination, the TOE framework has aroused increasing attention and been applied in the elements and factors studies of technology innovation among research fields such as tourism, manufacturing (3D printing, RFID, etc.), business (electronic data interchange, customer relationship management, etc.), and project management [34-39]. As indicated by previous studies, the TOE framework is supported by an abundance of empirical results, so it offers a solid foundation to unravel the conundrum behind project owners' BIM adoption decisions. 


\section{Theory and Hypotheses}

In this study, we extend the classical TAM by identifying "social influence", "organizational support", "BIM features", and "government BIM policies" based on the TOE framework as external variables and propose a conceptual model to predict project owners' BIM adoption behavior (see Figure 3). The model is explained with detailed research hypotheses in the following section.

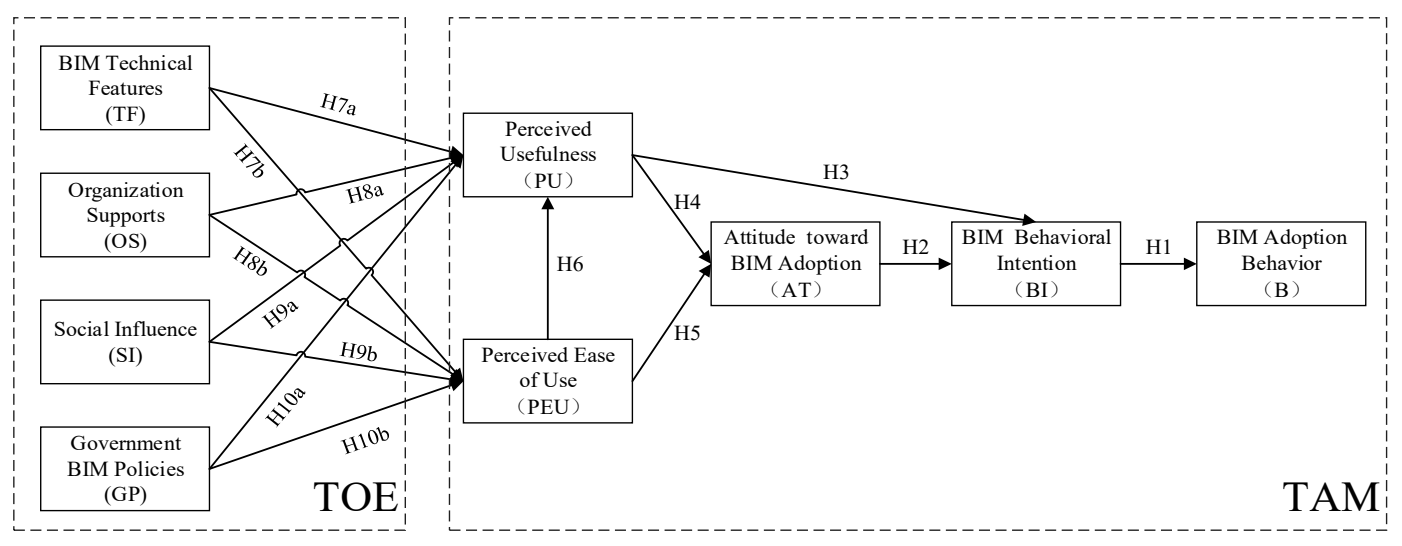

Figure 3. A technology-organization-environment (TOE)- and technology acceptance model (TAM)-based model of project owners' building information modeling (BIM) adoption behavior.

\subsection{BIM Behavioral Intention and BIM Adoption Behavior}

Behavioral intention is defined as "an indication of an individual's readiness to perform a given behavior". Therefore, behavioral intention is assumed to be an immediate antecedent of behavior [40]. Based on findings from case studies, Arayici et al. [41] found that the rapid promotion of BIM in the UK is benefitted precisely from the user's adoption decision, which leads to wide BIM adoption. Accordingly, we propose the following hypothesis:

H1. Behavioral intention will have a positive influence on BIM adoption behavior.

\subsection{Attitude toward BIM and BIM Behavioral Intention}

Attitude refers to one's subjective positive or negative judgment of a technology. Previous studies have shown that attitude has a certain influence on behavioral intention. Through investigating American consumers' behavior of car buying, Etter [42] found that attitudes can significantly affect purchase intentions. In addition, in a Taiwanese study focusing on online shopping, $\mathrm{Wu}$ [43] also found that attitudes directly influence purchasing decisions. Hereby, we propose the following hypothesis:

H2. Attitude toward BIM adoption will positively affect the BIM behavioral intention.

\subsection{Perceived Usefulness and BIM Behavioral Intention}

Perceived usefulness refers to the degree to which a person believes that using a particular technology would enhance his/her job performance [27]. Previous studies have proved that perceived usefulness has a direct effect on users' behavioral intention to use a technology [44,45]. Studies on BIM adoption in South Korea indicate that the perceived usefulness of BIM will significantly affect the behavioral intention of all parties involved in the construction industry [21,46]. Based on the comparative study of the acceptance of BIM in South Korea and the United States, Lee et al. [47] found that perceived usefulness had a significant impact on BIM behavioral intention at both the individual level and organizational level. Accordingly, we propose the following hypothesis:

H3. Perceived usefulness will positively affect BIM behavioral intention. 


\subsection{Perceived Usefulness, Perceived Ease of Use and Attitude toward BIM Adoption}

In line with the TAM, perceived usefulness and perceived ease of use are essential variables framing an individual's technology acceptance behavior. Studies on the adoption of information technology have shown that perceived usefulness and perceived ease of use can have a significant impact on users' attitudes toward BIM Adoption [27,48]. In addition, in the context of BIM adoption, perceived ease of use also shows a positive effect on perceived usefulness [24]. We, thus, propose the following hypotheses:

H4. Perceived usefulness of BIM will positively affect attitude toward BIM adoption.

H5. Perceived ease of use will positively affect attitude toward BIM adoption.

H6. Perceived ease of use has a positive effect on perceived usefulness of BIM.

\subsection{Social Influence, Perceived Usefulness and Perceived Ease of Use}

Social influence refers to the degree of an individual's perception that most people who are important to him think he should or should not perform the behavior in question [49]. The rationale for a direct effect of social influence on perceived usefulness and perceived ease of use is that people may choose to accept the same perspective, even if they are not so favorable toward the opinions. If they believe one or more important referents (such as superiors, peers, partners, etc.), they are sufficiently motivated to comply with the referents (especially superiors) based on affiliation and/or respect [50]. In an early study on bandwagon innovation diffusion, Rosenkopf and Abrahamson [51] pointed out that bandwagons have a positive feedback loop in which information generated by more adoptions creates a stronger bandwagon pressure, and a stronger bandwagon pressure prompts more adoptions. Therefore, a successful BIM application by competitors and partners will, to some extent, affect project owners' perception of the usefulness and usability of this innovative technology, which, in turn, affects BIM adoption as a whole $[11,25]$. Accordingly, this study proposes the following hypotheses:

H7a. Social influence has a positive influence on project owners' perceived usefulness of BIM.

H7b. Social influence has a positive influence on project owners' perceived ease of use of BIM.

\subsection{Organizational Support, Perceived Usefulness and Perceived Ease of Use}

Organizational support refers to an individual's perception on the degree of policy, resources and other kinds of support provided by the organization for the use of technology. Herein, it refers to the support provided by the project organization to the project owner to adopt BIM. Organizational support carries great weight in motivating employees' potential, allocating resources and enhancing work performance [52-54]. It is easily understandable that sufficient organizational support will exert an incentive effect on employees and improve their sense of organizational backup. Gaining strong support from their organizations, employees will have a sense of being trusted which fulfills their expectation, making them more dedicated to their job, and more likely to demonstrate that they can achieve the organizational goals. However, if employees lose the necessary support (such as information, resources, equipment or training, etc.), their work procedures and work quality will be adversely affected, leading to employees' becoming upset and eventually frustrated $[55,56]$.

In the information technology field, Lin et al. [57] found that organizational high-level support can improve employees' perceived usefulness and perceived ease of use of information technology. Recently, Song et al. [12] implied that, as a new project management technology, successful BIM adoption cannot be realized without the superincumbent financial and policy support in the early stage of software and hardware procurement and personnel training. Furthermore, there is some evidence showing that due to the fact that BIM is often not launched or advocated by the leader or 
decision-makers in organizations, it often fails to allocate sufficient human, material and financial resources to support BIM adoption [58]. Based on the above, we propose two hypotheses:

H8a. Organizational support to adopt BIM will positively impact project owners' perceived usefulness of BIM.

H8b. Organizational support to adopt BIM will positively impact project owners' perceived ease of use of BIM.

\subsection{BIM Technical Features, Perceived Usefulness and Perceived Ease of Use}

BIM technical features normally reflect the fitness, ease, compatibility and interoperability of BIM application. In line with a theory of innovation diffusion, Rogers [59] pointed out that the application of an innovation technology needs to be consistent with the existing value, demand and the experience of potential adopters. In particular, when it comes to introducing or adopting a new technology, firms will compare it with the existing technology, and consider the relevant advantages and characteristics of the two technologies in various aspects. Despite the huge potential value, if BIM is ineffective at interoperating or fitting current work procedures, it will not likely be accepted and adopted by project owners within a short period, as these project owners would be greatly concerned about the risk of abundant inputs (such as financial investments, human resources, etc.). Kim et al. [46] identified major obstacles to BIM adoption, including the actual software operation, the complexity of BIM workflows and the gap between the actual expectations of organizations. Evidence from previous studies clearly indicates that the lack of compatibility between different BIM software hinders the successful application of BIM in the construction industry $[13,60]$. For example, the compatibility of BIM will significantly affect users' perceived ease of use [21]. Accordingly, this study proposes the following hypotheses:

H9a. BIM technical features will have a positive effect on project owners' perceived usefulness of BIM.

H9b. BIM technical features will have a positive effect on project owners' perceived ease of use of BIM.

\subsection{Government BIM Policies, Perceived Usefulness and Perceived Ease of Use}

Government BIM policies generally refer to related policies issued by the government to promote BIM adoption. As shown in the Report of Business Value of BIM in China [58], the respondents who are project owners asserted that lacking first-hand experience deters them from joining BIM adoption and application practices. Even after the project owners adopted BIM, they usually need to emulate the existing projects which successfully applied BIM to guide their actual BIM applications and implementation. Thus, if the government could launch BIM pilot projects in batches and develop guidance for BIM application, this would significantly reduce the difficulty of BIM application, which would be likely to attract more project owners to adopt BIM in the first place. Some countries' experience has proven that appropriate financial subsidies would merit BIM adoption and application (such as in Singapore). For example, Succar [61] and Eadie et al. [62] indicated that government policies are among the primary factors influencing BIM adoption. Therefore, we propose the following hypotheses:

H10a. Government BIM policies will have a positive effect on project owners' perceived usefulness of BIM.

H10b. Government BIM policies will have a positive effect on project owners' perceived ease of use of BIM.

\section{Research Method}

\subsection{Measurements and Pilot Survey}

A structured questionnaire with two sections was designed and used for data collection. The first section covered demographic information of respondents including gender, age, education background, position, work experience and BIM experience. The second section included 24 measurement items (see Table 1 for details) which were designed to elicit project owners' assessments of BIM adoption 
on a five-point Likert-type scale, with 1-5 indicating "strongly disagree", "disagree", "generally", "agree" and "strongly agree", respectively. All of these measurements were adopted from existing studies and reworded to render the items relevant to BIM adoption for project owners in China. Specifically, perceived usefulness (PU), perceived ease of use (PEOU), attitude (AT), and behavioral intention (BI) were developed based on the measures previously validated by Davis $[27,28,46,63,64]$ and $\mathrm{Xu}$ et al. [18], and were reworded in accordance with the context of BIM adoption among Chinese project owners. Social influence (SI) was adopted from Kim et al. [46], Venkatesh and Davis [63], and contains the two dimensions of authoritative influences by intra-firm and inter-firm individuals and associations. Organizational support (OS) was operationalized to reflect the different impacts that the organization's resources exert on BIM adoption. Similar items had previously been validated by $\mathrm{Xu}$ et al. [18] and Cao et al. [25]. The construct of BIM technical features (TF) is derived from the research of $\mathrm{Xu}$ et al. [18], Kim et al. [46] and Song et al. [12] on the basis of BIM adoption practice in mainland China, with three items indicating the degree of interoperability and compatibility and fitness of BIM in project owners' daily tasks. Referring to the study of Song et al. [12], we replenished and extended the connotations of the vital construct, "Government BIM Policies"(GP), with distinctive Chinese characteristics. Therewith, three BIM experts who have eminent experience in BIM research and application were invited to participate in the pilot survey. Shortly after the pilot survey was conducted, the experts were asked to provide advice regarding the refinement of items and their personal understanding of BIM adoption. According to the experts' advice, items with ambiguity were refined, and the items with tautology were eliminated. After that, we sent the modified measurement items to these experts again and asked them to review whether the amendments strictly complied with their intentions to ensure the applicability of measurement items. The ultimate measurement items of these constructs are provided in Table 1.

Table 1. Measurement items.

\begin{tabular}{|c|c|c|c|}
\hline Variables & & Items & Sources \\
\hline Social Influence (SI) & $\begin{array}{l}\text { SI1 } \\
\text { SI2 } \\
\text { SI3 }\end{array}$ & $\begin{array}{l}\text { My colleague suggests that I should use BIM at work. } \\
\text { Top management thinks that I should use BIM at work. } \\
\text { Cooperative partners think that I should use BIM at work. }\end{array}$ & {$[44,63]$} \\
\hline Organization Support (OS) & $\begin{array}{l}\text { OS1 } \\
\text { OS2 } \\
\text { OS3 }\end{array}$ & $\begin{array}{l}\text { My organization provides good BIM training for BIM use. } \\
\text { My organization allocates sufficient funds for BIM facilities. } \\
\text { There are enough professionals in my organization to support } \\
\text { BIM use. }\end{array}$ & {$[16,23]$} \\
\hline BIM Technical Features (TF) & $\begin{array}{l}\text { TF1 } \\
\text { TF2 } \\
\text { TF3 }\end{array}$ & $\begin{array}{l}\text { BIM fits my daily tasks. } \\
\text { BIM is equal to my work demand. } \\
\text { BIM is of interoperability with other technology platforms. }\end{array}$ & {$[16,44,56]$} \\
\hline Government BIM Policies (GP) & $\begin{array}{l}\text { GP1 } \\
\text { GP2 } \\
\text { GP3 }\end{array}$ & $\begin{array}{l}\text { It is in favor of reducing the cost of BIM use if government } \\
\text { exerts the subsidy policy for our BIM implementation. } \\
\text { It will provide useful guidance for BIM use if government can } \\
\text { launch a BIM pilot program. } \\
\text { It will promote BIM use if government streamlines the } \\
\text { approval procedures of BIM projects. }\end{array}$ & [56] \\
\hline Perceived Usefulness (PU) & $\begin{array}{l}\text { PU1 } \\
\text { PU2 } \\
\text { PU3 }\end{array}$ & $\begin{array}{l}\text { Using BIM will reduce the time of finishing tasks. } \\
\text { Using BIM will enhance my job performance. } \\
\text { It would provide more chance to get promoted or raises if I } \\
\text { can use BIM. }\end{array}$ & {$[25,26]$} \\
\hline Perceived Ease of Use (PEU) & $\begin{array}{l}\text { PEU1 } \\
\text { PEU2 } \\
\text { PEU3 }\end{array}$ & $\begin{array}{l}\text { It is easy to learn and on top of BIM. } \\
\text { I can easily and skillfully use BIM to handle work tasks } \\
\text { Overall, I think BIM is easy to use. }\end{array}$ & {$[25,26]$} \\
\hline Attitude toward BIM (AT) & $\begin{array}{l}\text { AT1 } \\
\text { AT2 }\end{array}$ & $\begin{array}{l}\text { I do not resist using BIM in my work. } \\
\text { I like using BIM in my work. }\end{array}$ & {$[26,65]$} \\
\hline Behavioral Intention (BI) & $\begin{array}{l}\text { BI1 } \\
\text { BI2 }\end{array}$ & $\begin{array}{l}\text { I would like to use BIM in my work. } \\
\text { I expect that my frequency of BIM will increase in the future. }\end{array}$ & {$[44,63]$} \\
\hline BIM Behavior (B) & $\begin{array}{l}\text { B1 } \\
\text { B2 }\end{array}$ & $\begin{array}{c}\text { I will use BIM at work. } \\
\text { I will recommend BIM to others (colleagues, friends, etc.) }\end{array}$ & [65] \\
\hline
\end{tabular}




\subsection{Sampling and Data Collection}

In this study, we targeted project owners in mainland China involved in BIM adoption as qualified respondents for data collection. A total of 300 questionnaires were distributed by means of face-to-face interviews (number: 200) and an online survey platform (number: 100). In the face-to-face part, before the formal survey, we conducted an interview with each interviewee to ensure that he/she had first-hand experience of BIM practice. As for the online channel, targeted delivery was the only step taken to send the questionnaire to the preselected project owners involved in BIM adoption. In addition, to obtain sufficient samples, a snowball sampling method was utilized to increase the sample size as we invited the surveyed respondents to share more information regarding knowledgeable participants in other BIM projects or organizations. Any questionnaire with incomplete information or missing values was excluded. Finally, 188 valid questionnaires were received $(156(83 \%)$ from the face-to-face interviews and $32(17 \%)$ from the online platform). The valid response rate of face-to-face interviews was $78 \%$, and that of the online survey was $32 \%$. Among these respondents, $64.9 \%$ were male, and the remaining respondents were female. All of them were practitioners undertaking tasks directly related to BIM practice in the client departments. The demographics of the respondents under investigation are presented in Table 2.

Table 2. Demographics of the respondents $(\mathrm{N}=188)$.

\begin{tabular}{cccc}
\hline Variables & Category & Frequency & Percentage (\%) \\
\hline \multirow{2}{*}{ Gender } & Male & 122 & 64.9 \\
& Female & 66 & 35.1 \\
\hline \multirow{2}{*}{ Age } & $22 \sim 25$ & 117 & 62.2 \\
& $26 \sim 35$ & 63 & 33.5 \\
& $36 \sim 45$ & 5 & 2.7 \\
Education & Above 45 & 3 & 1.6 \\
& Associate Degree and below & 26 & 13.9 \\
& Bachelor's Degree & 124 & 66.0 \\
& Master's Degree and above & 38 & 20.1 \\
\hline \multirow{3}{*}{ Position } & BIM operation specialist & 133 & 70.7 \\
& BIM engineer & 40 & 21.3 \\
& BIM program manager & 9 & 4.8 \\
& Executive BIM manager & 6 & 3.2 \\
\hline \multirow{2}{*}{ Work experience } & $0 \sim 3$ years & 133 & 70.7 \\
& $3 \sim 5$ years & 22 & 11.7 \\
& $5 \sim 10$ years & 19 & 10.1 \\
& Above 10 years & 14 & 7.4 \\
\hline \multirow{2}{*}{ BIM experience } & $0 \sim 3$ years & 174 & 92.6 \\
& $3 \sim 5$ years & 9 & 4.8 \\
& $5 \sim 10$ years & 3 & 1.6 \\
& Above 10 years & 2 & 1.1 \\
\hline
\end{tabular}

\section{Data Analyses and Results}

In this study, confirmatory and discriminant factor analyses of the measurement model were first conducted in order to assess the reliability and validity of the proposed constructs. Afterwards, the maximum likelihood estimate (MLE) method of the structural equation model (SEM) was employed to validate the hypotheses and the fitness of the proposed model.

\subsection{Measurement Validation}

In general, reliability and validity were the two most common indicators used to evaluate the measurement model. The reliability of the measurement for each construct can be assessed on the basis 
of Cronbach's $\alpha$ coefficient. Previous studies suggested that a Cronbach's $\alpha$ greater than 0.7 indicates acceptable reliability [66,67]. All of the Cronbach's $\alpha$ coefficient values in the present study are more than the threshold of 0.7 (see Table 3 for detailed values), which indicates good reliability.

With regard to validity, convergent and discriminant validity should both be taken into account. On one hand, convergent validity is usually assessed by three indices: composite reliability (CR), average variance extracted (AVE), and standardized factor loadings. For the composite reliability (CR), values of 0.7 or higher are recommended, according to Nunnally et al. [66] and Nunnally and Bemstein [68]. The CR values in this study range from 0.811 to 0.933 , which satisfy the recommended value of 0.7 (see Table 3). In addition, as one of the indices to access the convergent validity, the AVE is often used by examining the construct relative to the amount of variance attributed to the measurement error [69]. With regard to Segars [70], the AVE value for each construct which exceeds the threshold of 0.5 is acceptable. In our study, the AVE values all meet the acceptable requirement (which all range from 0.633 to 0.846 ). Moreover, values of all standardized factor loadings in this study are above the threshold of 0.7. Therefore, all of the indices are satisfied at acceptable levels, demonstrating the convergent validity of the measure model.

Table 3. Convergent validity of the measurement model.

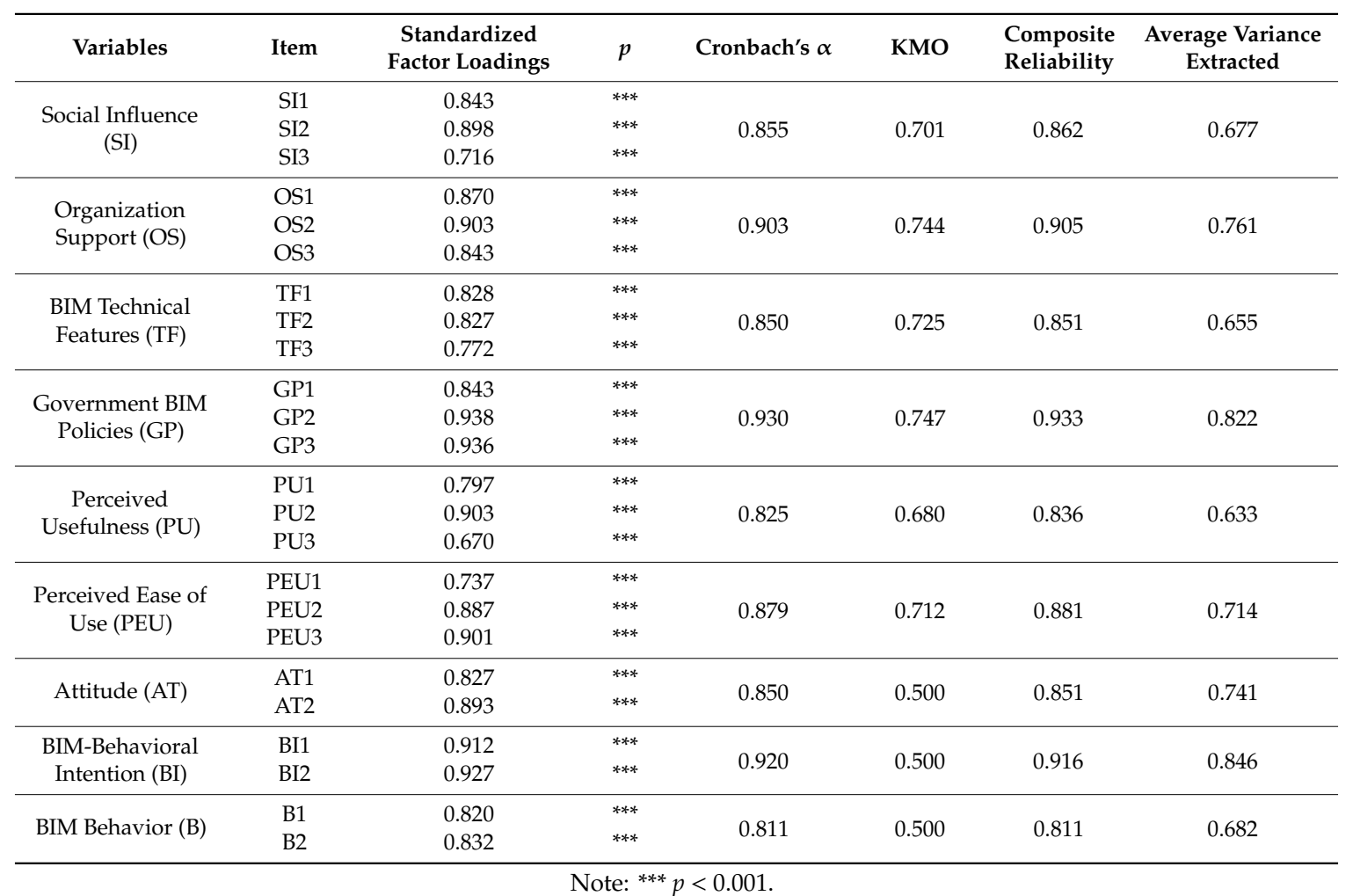

On the other hand, discriminant validity is mainly used to demonstrate the non-correlation between one given construct and the others which ought not be correlated with the given one [69]. Normally, the discriminant validity of one item is judged based on whether it can be easily determined as good or bad by comparing the square root of the AVE for the given construct with the correlations between that construct and all others. If the square roots of the AVE of one given construct are greater than all correlation coefficients of other constructs, it implies that the given construct is more likely to be strongly correlated with its own indicators than the other constructs in the model. In this study, the square roots of all the average variances extracted (the diagonal elements) are greater than the values of the off-diagonal correlation coefficients in the corresponding columns in Table 4, which confirms good discriminant validity as a whole. 
Table 4. Correlation matrix and the square of average variance extracted.

\begin{tabular}{cccccccccc}
\hline & GP & TC & OS & SI & PEU & PU & AT & BI & B \\
\hline GP & $\underline{0.907}$ & & & & & & & & \\
TC & 0.573 & $\underline{0.809}$ & & & & & & & \\
OS & 0.581 & 0.570 & $\underline{0.872}$ & & & & & & \\
SI & 0.626 & 0.465 & 0.659 & $\underline{0.823}$ & & & & \\
PEU & 0.375 & 0.377 & 0.462 & 0.452 & $\underline{0.845}$ & & & \\
PU & 0.726 & 0.608 & 0.524 & 0.594 & 0.486 & $\underline{0.796}$ & & & \\
AT & 0.547 & 0.480 & 0.461 & 0.497 & 0.507 & 0.675 & $\underline{0.861}$ & & \\
BI & 0.486 & 0.423 & 0.401 & 0.435 & 0.433 & 0.598 & 0.729 & $\underline{0.920}$ & \\
B & 0.344 & 0.300 & 0.284 & 0.308 & 0.307 & 0.424 & 0.516 & 0.680 & $\underline{0.826}$ \\
\hline
\end{tabular}

Note: The diagonal numbers underlined represent the square of average variance extracted.

\subsection{Hypotheses Testing}

With the aid of AMOS 21.0, the maximum likelihood estimate (MLE) method in the structural equation model (SEM) was employed to validate the hypotheses and the fitness between the proposed model and the collected data.

The fitness of the proposed model is revealed by the indices of the ratio of the Chi-square model and degrees of freedom $\left(\chi^{2} / \mathrm{df}\right)$, goodness-of-fit (GIF), root mean square error approximation (RMSEA), normed fit index (NFI), comparative fit index (CFI), incremental fit index (IFI), and Tacker-Lewis index (TLI). The recommend criteria of a goodness-of-fit and the values of these indices derived from this study are shown in Table 5. Despite the GFI and NFI being slightly lower than the recommended acceptable value of 0.90 , they are close enough to suggest that the model fits the data reasonably well.

Table 5. Evaluation of overall fitness of the conceptual model.

\begin{tabular}{ccc}
\hline Fitness Index & Recommended Value & Value \\
\hline$\chi^{2} / d f$ & $<3$ & 2.167 \\
GIF & $\geq 0.9$ & 0.826 \\
RMSEA & $<0.08$ & 0.079 \\
CFI & $\geq 0.9$ & 0.925 \\
NFI & $\geq 0.9$ & 0.871 \\
IFI & $\geq 0.9$ & 0.926 \\
TLI & $\geq 0.9$ & 0.911 \\
\hline
\end{tabular}

Then, a path analysis is carried out to test the hypotheses. As the results in Table 6 show, nine of fourteen hypotheses are supported. Similar to findings in some previous studies $[22,40,63,71]$, behavioral intention (BI) has a significant positive impact on behavior $(\beta=0.698, t=10.581, p<0.001)$, supporting H1. Furthermore, attitude has a significant positive impact on behavioral intention ( $\beta=0.886, t=5.854, p<0.001)$, which means that $\mathrm{H} 2$ is supported. However, an unexpected outcome is that PU has no significant impact on BI; thus, H3 is not supported. Furthermore, both PU and PEOU have significantly positive impacts on attitude $(\beta=0.476, \mathrm{t}=6.060, p<0.001 ; \beta=0.404, \mathrm{t}=4.391$, $p<0.001$ ), and therefore $\mathrm{H} 4$ and $\mathrm{H} 5$ are supported. Meanwhile, $\mathrm{H} 6$ is also supported given that PEOU has a significantly positive influence on $\mathrm{PU}(\beta=0.282, \mathrm{t}=3.388, p<0.001)$. Social influence (SI), on the one hand, is found to have a significantly positive impact on PEOU $(\beta=0.134, t=2.901, p<0.01)$, supporting H7b, but on the other hand, SI has no significant influence on PU $(\beta=0.134, t=1.735)$. OS has no significant impact on either PU or PEOU ( $\beta=-0.123, t=-1.779 ; \beta=0.134, t=1.765)$. In addition, the results show that TF has significant impacts on both PU and PEOU ( $\beta=0.489, \mathrm{t}=4.586$, $p<0.001 ; \beta=0.286, \mathrm{t}=2.565, p<0.01$ ). Therefore, both H9a and H9b are supported by the empirical results. GP has a significant impact on $\mathrm{PU}(\beta=0.291, \mathrm{t}=4.309, p<0.001)$, while it has no significant impact on PEOU ( $\beta=-0.012, \mathrm{t}=-0.155)$. Thus, H10a is supported but H10b is not. 
Table 6. Results of the tested hypotheses.

\begin{tabular}{|c|c|c|c|c|c|c|}
\hline Hypothesis & Relationship & $\beta$ & $\begin{array}{l}\text { Standardized } \\
\text { Error }\end{array}$ & $\begin{array}{c}\text { Critical Ratio } \\
(t \text {-Value })\end{array}$ & $p$ & Results \\
\hline H1 & $\mathrm{B} \leftarrow \mathrm{BI}$ & 0.698 & 0.066 & 10.581 & $* * *$ & Supported \\
\hline $\mathrm{H} 2$ & $\mathrm{BI} \leftarrow \mathrm{AT}$ & 0.886 & 0.151 & 5.854 & $* * *$ & Supported \\
\hline $\mathrm{H} 3$ & $\mathrm{BI} \leftarrow \mathrm{PU}$ & 0.054 & 0.122 & 0.439 & 0.661 & $\begin{array}{c}\text { Not } \\
\text { supported }\end{array}$ \\
\hline $\mathrm{H} 4$ & $\mathrm{AT} \leftarrow \mathrm{PU}$ & 0.476 & 0.079 & 6.060 & $* * *$ & Supported \\
\hline H5 & $\mathrm{AT} \leftarrow \mathrm{PEOU}$ & 0.404 & 0.092 & 4.391 & $* * *$ & Supported \\
\hline H6 & $\mathrm{PU} \leftarrow \mathrm{PEOU}$ & 0.282 & 0.083 & 3.388 & $* * *$ & Supported \\
\hline $\mathrm{H7a}$ & $\mathrm{PU} \leftarrow \mathrm{SI}$ & 0.130 & 0.075 & 1.735 & 0.083 & $\begin{array}{c}\text { Not } \\
\text { supported }\end{array}$ \\
\hline $\mathrm{H} 7 \mathrm{~b}$ & $\mathrm{PEOU} \leftarrow \mathrm{SI}$ & 0.240 & 0.083 & 2.901 & $* *$ & Supported \\
\hline $\mathrm{H} 8 \mathrm{a}$ & $\mathrm{PU} \leftarrow \mathrm{OS}$ & -0.123 & 0.069 & -1.779 & 0.075 & $\begin{array}{c}\text { Not } \\
\text { supported }\end{array}$ \\
\hline $\mathrm{H} 8 \mathrm{~b}$ & $\mathrm{PEOU} \leftarrow \mathrm{OS}$ & 0.134 & 0.076 & 1.765 & 0.078 & $\begin{array}{c}\text { Not } \\
\text { supported }\end{array}$ \\
\hline $\mathrm{H} 9 \mathrm{a}$ & $\mathrm{PU} \leftarrow \mathrm{TF}$ & 0.489 & 0.107 & 4.586 & $* * *$ & Supported \\
\hline $\mathrm{H} 9 \mathrm{~b}$ & $\mathrm{PEOU} \leftarrow \mathrm{TF}$ & 0.286 & 0.111 & 2.565 & $* *$ & Supported \\
\hline $\mathrm{H} 10 \mathrm{a}$ & $\mathrm{PU} \leftarrow \mathrm{GP}$ & 0.291 & 0.067 & 4.309 & $* * *$ & Supported \\
\hline $\mathrm{H} 10 \mathrm{~b}$ & $\mathrm{PEOU} \leftarrow \mathrm{GP}$ & -0.012 & 0.075 & -0.155 & 0.877 & $\begin{array}{c}\text { Not } \\
\text { supported }\end{array}$ \\
\hline
\end{tabular}

Note: ${ }^{* *} p<0.001 ;{ }^{* *} p<0.01 ;{ }^{*} p<0.05$.

\section{Discussion and Implications}

\subsection{Discussion}

The above results reveal that most of the proposed research hypotheses are well supported. As revealed by the results, project owners' behavior intention has a significantly positive impact on their BIM adoption behaviors, and their attitude will also positively influence their behavioral intention toward BIM adoption, which is consistent with the findings of Davis et al. [27], Ajzen [40], Yuan et al. [72] and Liu et al. [73]. However, we also found that the impact of perceived usefulness (PU) on behavioral intention is insignificant, which is contrary to the prediction of the classical TAM. Differing from previous TAM-based studies confirming that perceived usefulness (PU) has a significantly positive influence on attitude (AT), this study shows that attitude mediates between perceived usefulness and perceived ease of use. In BIM adoption cases for project owners, the impact of perceived usefulness (PU) on behavioral intention (BI) can be formed only across the "bridge" of attitude (AT). In addition, attitude is composed of three elements: inner feelings, emotions, and intentions, and these three elements are intersected with each other [74]. Therefore, perceived usefulness alone, without strong subjective inner feelings or desires, cannot transfer this perceived usefulness into a powerful driven force influencing behavioral intention, which echoes the dilemma that project owners are unwilling to step into actual BIM adoption although they have perceived the usefulness and great potential of BIM [58,75]. Both perceived usefulness (PU) and perceived ease of use (PEOU) positively influence the attitude. Specifically, the stronger the project owners' perceived usefulness and perceived ease-of-use of BIM, the more positive their attitude toward BIM adoption will be.

Additionally, social influence has no significant effect on perceived usefulness, while its impact on the perceived ease of use is significant. The explanation lies in that the impact of social influence on perceived usefulness will diminish as users' personal experience and cognition deepen over time [63]. Therefore, before the actual adoption, project owners' knowledge and beliefs about BIM are "vague and bandwagen", and they must therefore rely more on the opinions of others (such as top management and partners) as a basis for their intentions [76]. After implementation, when more information and details about BIM's strengths and weaknesses become clearer through direct experience, the social influence weakens [77]. On the other hand, social influence has a significant impact on perceived ease of use, indicating that when users' perceived ease of use of information technology is consistent with 
the external world, unlike perceived usefulness, their belief that the information technology (i.e., BIM) is easy to use will be further strengthened.

This study also presents an unexpected but interesting finding that organizational support has no significant influence on either perceived usefulness or perceived ease of use, which is in contrast to many previous research findings claiming that organizational support is a critical successful factor for BIM adoption and implementation $[11,13,18]$. These results could largely be explained by the differences in the demand of resources input and the actual effort exerted by top management to promote BIM adoption and implementation. Furthermore, the statements of the majority of survey respondents provide easily understandable reasons for why, in their organizations, management's support for BIM is inadequate to support comprehensive BIM application, which leads to a lack of necessity and incentive to use BIM. This parallels previous findings that employees' perception of organizational support influences whether employees will improve their organizational commitment and support organizational goals $[55,78]$. In turn, this finding indicates that organizational support will directly influence staff's perception and feelings regarding whether BIM is useful and easy to use, which consequently affects their ultimate adoption behavior.

Furthermore, it can be seen from Table 4 that BIM technical features (such as interoperability, compatibility, etc.) are the most important factors for determining project owners' decision on whether to adopt BIM. The result is consistent with the findings of previous studies [13], which state that the fitness and interoperability of BIM to the current tasks are critical factors influencing the owners' perceptions of the usefulness and ease of use of BIM and will ultimately constitute a BIM adoption behavior. Therefore, the matching degree of BIM's own task technology and how to improve users' perceived usefulness must be considered.

Besides, government BIM policies have a significantly positive effect on perceived usefulness. This is consistent with previous studies which revealed that the existence of government-led initiatives to promote BIM implementation within the industry is one of the critical success factors for extensive BIM adoption and diffusion [62,79]. On the one hand, government policies, such as subsidies, can directly reduce the BIM application costs, which in turn improve project benefits and attract more project owners to get involved in BIM adoption. On the other hand, a universal BIM standard supported by government will reduce the difficulty to interoperate among different special platforms $[11,18,58]$. Meanwhile, almost all project owners in our survey believe that government support for policies is very helpful for their BIM adoption.

\subsection{Theoretical Implications}

This study enriches the theoretical literature in three main areas.

Firstly, based on the theory of the TAM, this study categorizes different dimensions of factors and elements-which impact individuals' perceptions of the usefulness and ease of use of BIM-affecting project owners' BIM adoption behavior in the Chinese AEC sector, with an ultimate aim to explain why project owners might adopt BIM. The factors capable of explaining project owners' BIM adoption behaviors are tested and validated by using a structural equation model, and the intrinsic motivation and action mechanism of project owners' BIM adoption behavior are revealed. The findings provide a deeper understanding for explaining the causal factors leading to BIM adoption behaviors.

Secondly, this study's findings also provide valuable insights into the TOE framework and the theory of the TAM in a specific context. The results show that organizational support has no significant impact on either perceived usefulness or perceived ease of use, which can be explained by Eisenberger's findings "perceived organizational support is the premise of behavior, organizational support without perception cannot work even if the support is already provided [52]", indicating that there seems to be a certain precondition that organizational support could positively affect the behavior. Beyond this, another attracting result is that attitude mediates between perceived usefulness and perceived ease of use, which contracts with the findings of Venkatesh et al. [64], but agrees with the findings of Howard et al. [22]. 
Thirdly, this study extends the theory of the TAM by integrating the TOE framework, revealing that technical, organizational and environmental variables are significantly related to behavioral intention. These variables are intermediated by two distinct constructs (PU and PEOU) and attitude (AT) in a BIM adoption context. Furthermore, results also demonstrate that most of the proposed hypotheses are well supported and the causal relationships among the postulated constructs in the model are analyzed. As such, the model in our study provides an elaborated explanation of the key factors forming the behavioral intentions of project owners toward BIM adoption. In other words, the model offers important insights into the reasons behind project owners' willingness to adopt BIM. By investigating BIM adoption from project owners' perspectives, this study also responds to and reinforces the concern of Ling et al. [19], i.e., focusing on the adoption behavior of other project participants would add more dimensions and shed more light on construction innovation.

\subsection{Practical Implications}

BIM is often recognized as a promising platform for project stakeholders (including the project owner) to capture complete information throughout the project lifecycle, and to utilize the available data for sustainable design, sustainability rating analysis and sustainable facilities management. The findings of this study will help project owners to understand the impact and interaction of the external constraints and their own subjective perceptions of BIM adoption, based on which successful BIM adoptions and construction sustainability will be increased by some effective incentives and strategies.

Responding to many previous studies on technology acceptance, attitude, perceived usefulness and perceived ease of use are key determinants of behavioral intention $[28,40,43,48]$, which will lead to the ultimate BIM adoption behavior. Thus, project owners should break the traditional mindset, production-organization mode and work procedures to form a positive attitude to embrace a brand-new or even subversive paradigm based on BIM, leading to long-term sustainable growth not only for the organizations but also for the construction industry.

Among these proposed external antecedents, the technical feature is found to be of the utmost importance to perceived usefulness and perceived ease of use. This finding provides insights revealing that project owners must pay attention to the technical features (such as interoperability and compatibility) of the introduced BIM platform or tools, which would greatly enhance the likelihood of successful BIM adoption and sustainability rating analysis from the point of view of technical feasibility.

Furthermore, social influence has a significant impact on the perceived ease of use of project owners, affecting project owners' BIM adoption through attitudes and behavioral intentions. It is suggested that intensifying the dissemination of BIM's benefits and peer experience exchanges could enhance project owners' acknowledgement of BIM's benefits, thus effectively helping project owners' BIM adoption. Furthermore, as mentioned above, the effect of social influence diminishes as experience is gained. As such, project owners should attach importance to establishing a good corporate environment to embrace BIM adoption.

Lastly, government policies also have a positive impact on the perceived usefulness of BIM to project owners, which in turn indirectly affects their BIM adoption. This finding indicates that external incentives from government will help project owners' BIM adoption. In this regard, launching BIM pilot programs and tax exemption could be effective ways to create a favorable environment for promoting project owners' BIM adoption activities.

\section{Conclusions}

Based on the theory of the TAM, this study attempts to explain project owners' BIM adoption behaviors by investigating how different dimensions of factors and elements-which impact individuals' perceptions of usefulness and ease of use of BIM-influence project owners' BIM adoption behavior in the Chinese construction sector. The factors affecting project owners' BIM adoption are tested and validated by using a structural equation model, and the intrinsic motivation and action mechanism of project owners' BIM adoption behavior are revealed. 
The results indicated that most of the proposed hypotheses are well supported and the causal relationships among the postulated constructs in the model are analyzed. The model in our study provides an elaborated explanation of the key factors influencing the behavioral intentions of project owners toward BIM adoption. Particularly, the results reveal that BIM technical features and government BIM policies have positive effects on perceived usefulness, but social influence and organizational support do not significantly influence perceived usefulness. Furthermore, both social influence and BIM technical features have positive effects on perceived ease of use, while organizational support and government BIM policies do not significantly influence perceived ease of use. Attitude plays a significant intermediary role among perceived usefulness, perceived ease of use and behavior intention. Additionally, attitude significantly affects behavior intention, and behavior intention can also affect BIM adoption behavior. The findings of this study are expected to provide a better understanding of the essential elements of project owners' BIM adoption behaviors and guide industry practitioners in developing proper strategies to achieve more effective BIM implementation.

There are also limitations. Although this study deepens the understanding of project owners' BIM adoption intentions and behavior, a wider range of variables can be considered to enhance the model's robustness to more accurately predict project owners' BIM adoption behaviors. Also, despite some previous studies indicated that project features (such as project size, nature, delivery types, etc.) need to be taken into account when it comes to BIM adopting strategies, the limitation in sample data blocks us to conduct further examinations. Hence, research focusing on the influence of project features (such as project size, nature, delivery types, etc.) on BIM adoption behaviors should be further developed. Besides, extensive studies should be conducted to examine the generality of the proposed model in different countries' practice and background to expand the situations to which it applies.

Author Contributions: Conceptualization, H.Y. and X.X.; methodology, H.Y. and Y.Y.; software, Y.Y.; validation, Y.Y.; formal analysis, Y.Y.; investigation, Y.Y. and H.Y.; resources, H.Y. and X.X.; data collection, Y.Y.; writing—original draft preparation, Y.Y.; writing—-review and editing, H.Y.; funding acquisition, H.Y. and X.X.

Funding: This research was funded by the Major Program of the National Social Science Fund of China (Grant number: 18ZDA043), and the National Natural Science Foundation of China (Grant number: 71573216; 71671053).

Conflicts of Interest: There is no conflict of interest.

\section{References}

1. HM Government. Government Construction Strategy; HMSO: London, UK. Available online: https://www.gov. uk/government/publications/government-construction-strategy/ (accessed on 25 September 2018).

2. MOHURD. The Outline of Construction Informatization Development (2011 2015). MOHURD, PRC. Available online: http://www.gov.cn/gzdt/2011-05/19/content_1866641.htm (accessed on 9 October 2018). (In Chinese)

3. MOHURD. The Outline of Construction Informatization Development (2016 2020). MOHURD, PRC. Available online: http://www.mohurd.gov.cn/wjfb/201609/t20160918_228929.html (accessed on 9 October 2018). (In Chinese)

4. Eastman, C.; Teicholz, P.; Sacks, R.; Liston, K. BIM Handbook: A Guide to Building Information Modeling for Owners, Managers, Designers, Engineers and Contractors, 2nd ed.; Wiley: New York, NY, USA, 2011.

5. Adrieli, D.C.; Ariovaldo, G.; Vanessa, D.S. A systematic literature review on integrative lean and sustainability synergies over a building's lifecycle. Sustainability 2017, 9, 1156.

6. Kibert, C.J. Sustainable Construction: Green Building Design and Delivery; Wiley: Hoboken, NJ, USA, 2016.

7. Cao, D.P.; Li, H.; Wang, G.B.; Huang, T. Identifying and contextualizing the motivations for BIM implementation in construction projects: An empirical study in China. Int. J. Proj. Manag. 2017, 35, 658-669. [CrossRef]

8. Chong, H.Y.; Lopez, R.; Wang, J.; Wang, X.; Zhao, Z. Comparative analysis on the adoption and use of BIM in road infrastructure projects. J. Manag. Eng. 2016, 32, 05016021. [CrossRef]

9. Succar, B.; Sher, W.; Williams, A. An integrated approach to BIM competency assessment, acquisition and application. Autom. Constr. 2013, 35, 174-189. [CrossRef] 
10. Lee, S.; Yu, J.; Jeong, D. BIM acceptance model in construction organizations. J. Manag. Eng. 2015, 31, 04014048. [CrossRef]

11. Ozorhon, B.; Karahan, U. Critical Success factors of building information modeling implementation. J. Manag. Eng. 2017, 33, 04016054. [CrossRef]

12. Song, J.; Migliaccio, G.; Wang, G.; Lu, H. Exploring the influence of system quality, information quality, and external service on BIM user satisfaction. J. Manag. Eng. 2017, 33, 04017036. [CrossRef]

13. Won, J.; Lee, G.; Dossick, C.; Messner, J. Where to focus for successful adoption of building information modeling within organization. J. Constr. Eng. Manag. 2013, 139, 04013014. [CrossRef]

14. Chien, K.F.; Wu, Z.H.; Huang, S.C. Identifying and assessing critical risk factors for BIM projects: Empirical study. Autom. Constr. 2014, 45,1-15. [CrossRef]

15. Boktor, J.; Hanna, A.; Menassa, C. The state of practice of building information modeling (BIM) in the mechanical construction industry. J. Manag. Eng. 2014, 140, 05014011.

16. Bryde, D.; Broquetas, M.; Volm, J.M. The project benefits of building information modelling (BIM). Int. J. Proj. Manag. 2013, 31, 971-980. [CrossRef]

17. Jin, R.; Hancock, C.; Tang, L.; Chen, C.; Wanatowski, D.; Yang, L. Empirical study of BIM implementation-based perceptions among Chinese practitioners. J. Manag. Eng. 2017, 33, 04017025. [CrossRef]

18. Xu, H.; Feng, J.; Li, S. Users-orientated evaluation of building information model in the Chinese construction industry. Autom. Constr. 2014, 39, 32-46. [CrossRef]

19. Ling, F.; Hartmann, A.; Kumaraswamy, M.; Dulaimi, M. Influences on innovation benefits during implementation: client's perspective. J. Constr. Eng. Manag. 2007, 133, 306-315. [CrossRef]

20. Gu, N.; London, K. Understanding and facilitating BIM adoption in the AEC industry. Autom. Constr. 2010, 19, 988-999. [CrossRef]

21. Son, H.; Lee, S.; Kim, C. What drives the adoption of building information modeling in design organizations? An empirical investigation of the antecedents affecting architect's behavioral intentions. Autom. Constr. 2015, 49, 92-99. [CrossRef]

22. Howard, R.; Restrepo, L.; Chang, C.Y. Addressing individual perceptions: An application of the unified theory of acceptance and use of technology to building information modelling. Int. J. Proj. Manag. 2017, 35, 107-120. [CrossRef]

23. Liu, Y.; Nederveen, S.V.; Hertogh, M. Understanding effects of BIM on collaborative design and construction: An empirical study in China. Int. J. Proj. Manag. 2016, 35, 686-698. [CrossRef]

24. Wang, G.; Song, J. The relation of perceived benefits and organizational supports to user satisfaction with building information model (BIM). Comput. Hum. Behav. 2017, 68, 493-500. [CrossRef]

25. Cao, D.P.; Li, H.; Wang, G.B. Impacts of isomorphic pressures on BIM adoption in construction projects. J. Constr. Eng. Manag. 2014, 140, 04014056. [CrossRef]

26. Gledson, B.J.; Greenwood, D. The adoption of 4D BIM in the UK construction industry: An innovation diffusion approach. Eng. Constr. Archit. Manag. 2017, 24, 950-967. [CrossRef]

27. Davis, F.D. Perceived usefulness, perceived ease of use, and user acceptance of information technology. Mis Q. 1989, 13, 319-340. [CrossRef]

28. Davis, F.D.; Bagozzi, R.P.; Warshaw, P.R. User acceptance of computer technology: A comparison of two theoretical models. Manag. Sci. 1989, 35, 982-1003. [CrossRef]

29. Broman, T.M.; Schuitema, G.; Thogersen, J. Responsible technology acceptance: Model development and application to consumer acceptance of smart grid technology. Appl. Energy 2014, 134, 392-400. [CrossRef]

30. Manis, K.T.; Choi, D. The virtual reality hardware acceptance model (VR-ham): Extending and individuating the technology acceptance model (TAM) for virtual reality hardware. J. Bus. Res. 2019, 100, 503-513. [CrossRef]

31. Sarah, P.; Oliver, S.; Yasel, C. Acceptance of LNG as an alternative fuel: Determinants and policy implications. Energy Policy 2018, 120, 259-267.

32. Pratia, G.; Puchades, M.V.; Angelis, M.; Pietrantoni, L.; Fraboni, F.; Decarli, N.; Guerra, A.; Dardari, D. Evaluation of user behavior and acceptance of an on-bike system. Transp. Res. Part F Traffic Psychol. Behav. 2018, 58, 145-155. [CrossRef]

33. Legris, P.; Ingham, J.; Collerette, P. Why do people use information technology? A critical review of the technology acceptance model. Inf. Manag. 2003, 40, 191-204. [CrossRef] 
34. Kuan, K.K.Y.; Chau, P.Y.K. A perception-based model for EDI adoption in small businesses using a technology-organization-environment framework. Inf. Manag. 2001, 38, 507-521. [CrossRef]

35. Bosch-Rekveldt, M.; Jongkind, Y.; Mooi, H.; Bakker, H.; Verbraeck, A. Grasping project complexity in large engineering projects: The toe (technical, organizational and environmental) framework. Int. J. Proj. Manag. 2011, 29, 728-739. [CrossRef]

36. Wei, J.S.; Seedorf, S.; Lowry, P.B. The assimilation of RFID technology by Chinese companies: A technology diffusion perspective. Inf. Manag. 2015, 52, 628-642. [CrossRef]

37. Wang, Y.S.; Li, H.T.; Li, C.R.; Zhang, D.Z. Factors affecting hotel's adoption of mobile reservation systems: A technology-organization-environment framework. Tour. Manag. 2016, 53, 163-172. [CrossRef]

38. Yeh, C.C.; Chen, Y.F.; Phillips, F. Critical success factors for adoption of $3 \mathrm{~d}$ printing. Technol. Forecast. Soc. Chang. 2018, 132, 209-216. [CrossRef]

39. Cruz-Jesus, F.; Pinheiro, A.; Oliveira, T. Understanding CRM adoption stages: Empirical analysis building on the TOE framework. Comput. Ind. 2019, 109,1-13. [CrossRef]

40. Ajzen, I. The theory of planned behavior. Organ. Behav. Hum. Decis. Process. 1991, 50, 179-211. [CrossRef]

41. Arayici, Y.; Coates, P.; Koskela, L.; Kagioglou, M.; Usher, C.; O’Reilly, K. Technology adoption in the BIM implementation for lean architectural practice. Autom. Constr. 2011, 20, 189-195. [CrossRef]

42. Etter, W. Attitude theory and decision theory: Where is the common ground? J. Mark. Res. 1975, 12, 481-483. [CrossRef]

43. Wu, S. The relationship between consumer characteristics and attitude toward online shopping. Mark. Intell. Plan. 2003, 21, 37-44. [CrossRef]

44. Carolina, L.N.; Molina-Castillo, F.J.; Bouwman, H. An assessment of advanced mobile services acceptance: Contributions from tam and diffusion theory models. Inf. Manag. 2008, 45, 359-364.

45. Wu, C.S.; Cheng, F.F.; Yen, D.C.; Huang, Y.W. User acceptance of wireless technology in organizations: A comparison of alternative models. Comput. Stand. Interfaces 2011, 33, 50-58. [CrossRef]

46. Kim, S.; Chin, S.; Han, J.; Choi, C. Measurement of construction BIM value based on a case study of a large-scale building project. J. Manag. Eng. 2017, 33, 05017005. [CrossRef]

47. Lee, S.; Yu, J. Comparative study of BIM acceptance between Korea and the United States. J. Constr. Eng. Manag. 2016, 142, 05015016. [CrossRef]

48. Ronny, S.; Fazilat, S.; Jo, T. The technology acceptance model (TAM): A meta-analytic structural equation modeling approach to explaining teachers' adoption of digital technology in education. Comput. Educ. 2019, $128,13-35$.

49. Deutsch, M. A study of normative and informational social influence on individual judgment. J. Abnorm. Soc. Psychol. 1955, 51, 629-636. [CrossRef]

50. Bagozzi, R.P.; Lee, K.H. Multiple routes for social influence: The role of compliance, internalization, and social identity. Soc. Psychol. Q. 2002, 65, 226-247. [CrossRef]

51. Rosenkopf, L.; Abrahamson, E. Modeling reputational and informational influences in threshold models of bandwagon innovation diffusion. Comput. Math. Organ. Theory 1999, 5, 361-384. [CrossRef]

52. Eisenberger, R.; Fasolo, P.; Davis LaMastro, V. Perceived organizational support and employee diligence, commitment, and innovation. J. Appl. Psychol. 1990, 75, 51-59. [CrossRef]

53. Shore, L.M.; Wayne, S.J. Commitment and employee behavior: Comparison of affective commitment and continuance commitment with perceived organizational support. J. Appl. Psychol. 1993, 78, 774-780. [CrossRef]

54. Pearce, C.L.; Herbik, P.A. Citizenship behavior at the team level of analysis: The effects of team leadership, team commitment, perceived team support, and team size. J. Soc. Psychol. 2004, 144, 293-310. [CrossRef]

55. Eisenberger, R.; Huntington, R.; Hutchison, S.; Sowa, D. Perceived organizational support. J. Appl. Psychol. 1986, 71, 500-507. [CrossRef]

56. Mcmillan, R. Customer Satisfaction and Organizational Support for Service Providers. Ph.D. Thesis, University of Florida, Gainesville, FL, USA, 1997.

57. Lin, H.-F. An investigation into the effects of is quality and top management support on ERP system usage. Total Qual. Manag. Bus. Excell. 2010, 21, 335-349. [CrossRef]

58. Dodge Data \& Analytics. Smart Market Report: The Business Value of BIM in China; Dodge Data \& Analytics: Bedford, MA, USA, 2015. (In Chinese)

59. Rogers, E.M. Diffusion of Innovation, 1st ed.; The Free Press: New York, NY, USA, 1983. 
60. Liu, R.; Issa, R.R.A. Factors influencing the adoption of building information modeling in the AEC Industry. In Proceedings of the International Conference on Computing in Civil and Building Engineering, Nottingham, UK, 30 June-2 July 2010.

61. Succar, B. Building information modelling framework: A research and delivery foundation for industry stakeholders. Autom. Constr. 2009, 18, 357-375. [CrossRef]

62. Eadie, R.; Browne, M.; Odeyinka, H.; Mckeown, C.; Mcniff, S. BIM implementation throughout the UK construction project lifecycle: An analysis. Autom. Constr. 2013, 36, 145-151. [CrossRef]

63. Venkatesh, V.; Davis, F.D. A theoretical extension of the technology acceptance model: Four longitudinal field studies. Manag. Sci. 2000, 46, 186-204. [CrossRef]

64. Venkatesh, V.; Morris, M.G.; Davis, G.B.; Davis, F.D. User acceptance of information technology: Toward a unified view. MIS Q. 2003, 27, 425-478. [CrossRef]

65. Lee, S.; Yu, J.H. Discriminant model of BIM acceptance readiness in a construction organization. KSCE J. Civ. Eng. 2017, 21, 555-564. [CrossRef]

66. Nunnally, J.C. Psychometric Theory, 2nd ed.; McGraw-Hill: New York, NY, USA, 1978.

67. Hair, J.F.; Anderson, R.E.; Tatham, R.L.; Black, W.C. Multivariate Data Analysis with Readings; Prentice-Hall: Upper Saddle River, NJ, USA, 1998.

68. Nunnally, J.C.; Bernstein, I.H. Psychometric Theory; McGraw-Hill: New York, NY, USA, 1994.

69. Fornell, C.; Larcker, D.F. Evaluating structural equation models with unobservable variables and measurement error. J. Mark. Res. 1981, 18, 39-50. [CrossRef]

70. Segars, A.H. Assessing the unidimensionality of measurement: A paradigm and illustration within the context of information systems research. Omega 1997, 25, 107-121. [CrossRef]

71. Baptista, G.; Oliveira, T. Understanding mobile banking: The unified theory of acceptance and use of technology combined with cultural moderators. Comput. Hum. Behav. 2015, 50, 418-430. [CrossRef]

72. Yuan, H.P.; Wu, H.Y.; Zuo, J. Understanding factors influencing project managers' behavioral intentions to reduce waste in construction projects. J. Manag. Eng. 2018, 34, 04018031. [CrossRef]

73. Liu, Y.; Hong, Z.; Zhu, J.; Yan, J.; Qi, J.; Liu, P. Promoting green residential buildings: residents' environmental attitude, subjective knowledge, and social trust matter. Energy Policy 2018, 112, 152-161. [CrossRef]

74. Myers, G.D. Social Psychology, 10th ed.; McGraw-Hill: Holland, MI, USA, 2010.

75. McGraw Hill Construction. The Business Value of BIM for Construction in Global Markets: How Construction around the World Are Driving Innovation with Building Information Modeling; McGraw Hill Construction: Bedford, MA, USA, 2014.

76. Hartwick, J.; Barki, H. Explaining the role of user participation in information system use. Manag. Sci. 1994, 40, 440-465. [CrossRef]

77. Agarwal, R.; Prasad, J. The role of innovation characteristics and perceived voluntariness in the acceptance of information technologies. Decis. Sci. 1997, 28, 557-582. [CrossRef]

78. Yu, C.; Frenkel, S.J. Explaining task performance and creativity from perceived organizational support theory: Which mechanisms are more important? J. Organ. Behav. 2013, 34, 1165-1181. [CrossRef]

79. Arayici, Y.; Coates, P. A system engineering perspective to knowledge transfer: A case study approach of BIM adoption. In Virtual Reality-Human Computer Interaction; Tan, X.-X., Ed.; InTech: Rijeka, Croatia, 2012; pp. 179-206.

(C) 2019 by the authors. Licensee MDPI, Basel, Switzerland. This article is an open access article distributed under the terms and conditions of the Creative Commons Attribution (CC BY) license (http://creativecommons.org/licenses/by/4.0/). 